
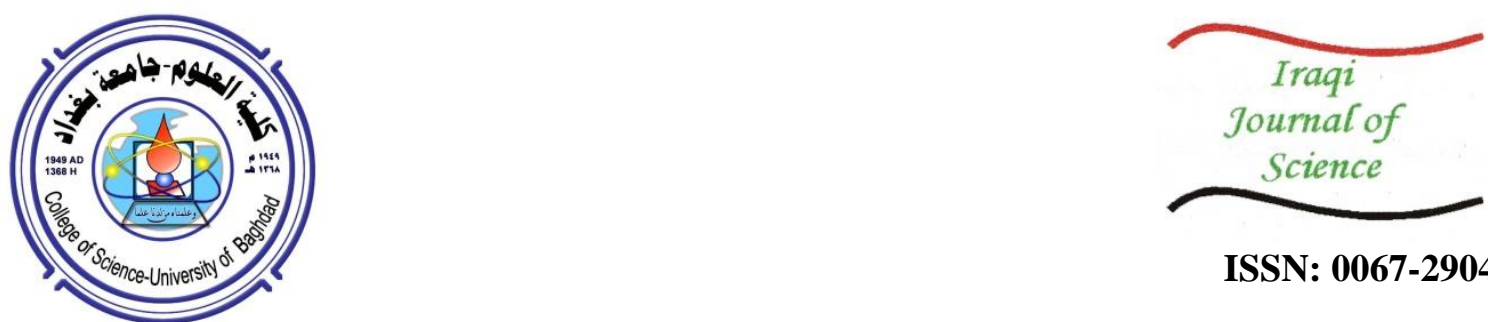

ISSN: 0067-2904

\title{
Heavy Metal Pollution and Sources in Dust from Primary Schools and Kindergartens in Ramadi City, Iraq
}

\author{
Athraa B. Radhi ${ }^{1}$, Sufyan M. Shartooh ${ }^{1}$, Emad A. Al-Heety $^{{ }^{2}}$ \\ ${ }^{1}$ Department of Biology, College of Science, University of Anbar, Iraq \\ ${ }^{2}$ Department of Applied Geology, College of Science, University of Anbar, Iraq
}

Received: $24 / 7 / 2020$

Accepted: 10/10/2020

\begin{abstract}
The aim of this study is to determine the level of pollution with heavy metals $(\mathrm{Cd}, \mathrm{Cr}, \mathrm{Cu}, \mathrm{Ni}, \mathrm{Pb}, \mathrm{Zn})$ and their potential sources in dust samples collected from schools in Ramadi City, Iraq. The dust samples were collected from 40 primary schools and two kindergartens and analyzed by using atomic absorption spectrophotometer. The heavy metal concentrations were found to follow the order $\mathrm{Cr}>\mathrm{Cu}>\mathrm{Pb}>\mathrm{Ni}>\mathrm{Zn}>\mathrm{Cd}$. The results indicated that the concentrations of $\mathrm{Cd}$, $\mathrm{Cu}$, and $\mathrm{Pb}$ exceeded the permitted background values. The pollution level was assessed using the geo-accumulation index $\left(\mathrm{I}_{\mathrm{geo}}\right)$ and pollution load index (PLI). The classification of dust samples according to $I_{\text {geo }}$ values showed that they ranged from unpolluted for $\mathrm{Cu}, \mathrm{Cr}, \mathrm{Ni}$, and $\mathrm{Zn}$, to moderately polluted for $\mathrm{Pb}$, and heavily polluted for $\mathrm{Cd}$. The PLI values indicated no to moderate pollution load. The results of the comparisons of heavy metal concentrations with the background values, as well as the multivariate statistical analysis, indicated three groups of heavy metals with different sources or origins: (1) $\mathrm{Cd}$ and $\mathrm{Cu}$ (anthropogenic source: vehicle emissions); (2) $\mathrm{Pb}$ (mixed source); and (3) $\mathrm{Cr}, \mathrm{Ni}$, and $\mathrm{Zn}$ (Geogenic source). This study is the first attempt in Iraq to investigate the concentrations of heavy metals in the dust of indoor environments. This study provides the environmental protection managers and decision-makers with important information about the concentrations of heavy metals and their sources in indoor environments.
\end{abstract}

Keywords: Heavy metal; Concentration; Indoor dust; Classroom;; Iraq

تلوث ومصادر العناصر الثقيلة في غبار الددارس الابتدائية ورياض الأطفال في مدينة الرمادي، العرق

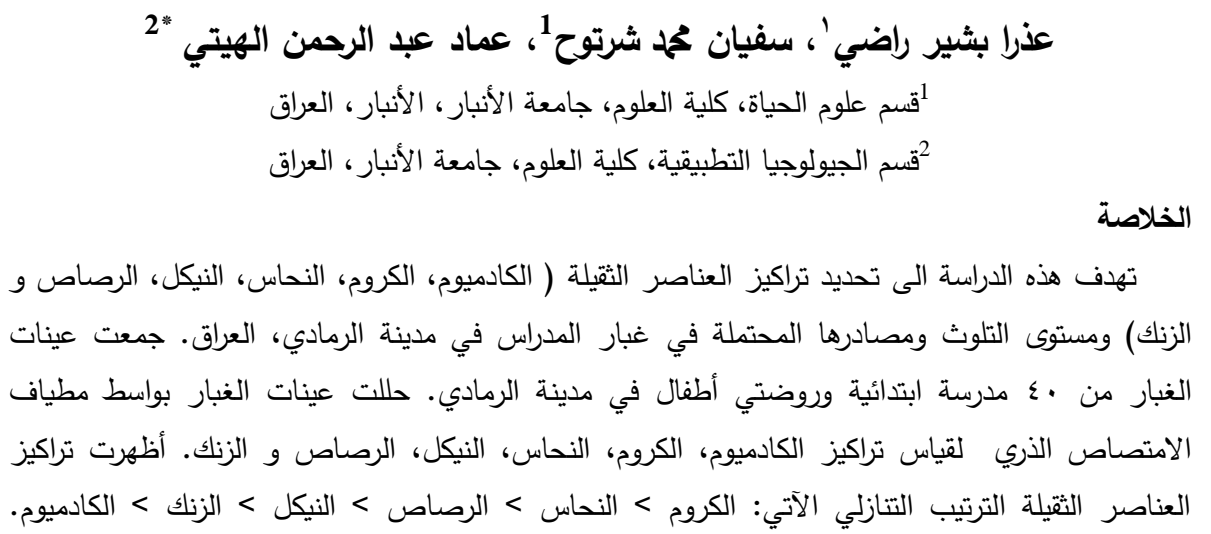




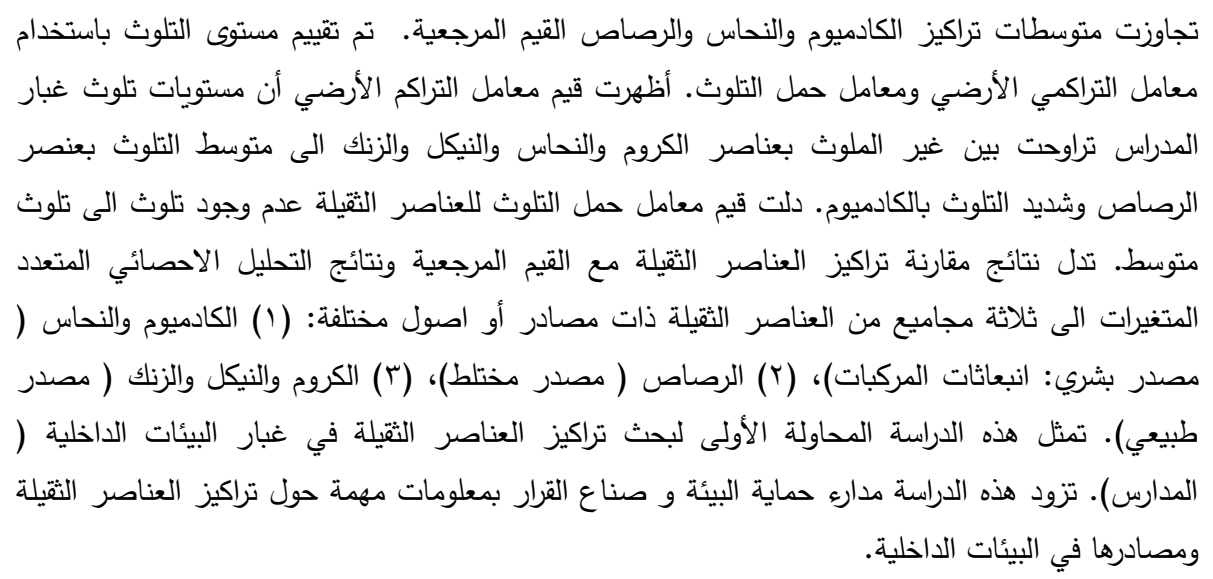

\section{Introduction}

The elevated concentrations of heavy metals in the different environmental media (water, air, soil, dust,... etc) is a serious environmental issue because of their toxicity, stability, non-degradability, and harmful effects on human health [1]. The high concentrations of heavy metals are due to the accelerated urbanization and industrialization associated with the development policies in different countries of the world [2]. A large number of studies focused on heavy metals pollution of outdoor environments, while less attention has been given to heavy metals pollution of indoor environments (buildings, houses, schools, ... etc.). The particulates and dust carrying organic and inorganic chemicals play an important role in modifying the indoor environmental quality [3]. Dust consists of solid materials or particulates in the form of fine powder $(<100 \mu \mathrm{m})$ settling on the ground or the surfaces of objects [4]. Dust is a source for heavy metals and organic pollutants [5]. Because of the small size of dust, its surface area is greater and, in turn, its ability to adsorb heavy metals is greater [6]. Since it has fine particles, dust can be easily entered into the human body through three routes, which are inhalation, ingestion, and dermal contact, causing health risks to humans in the long- term $[7,8,9]$. Many studies reported that the exposure to some heavy metals can lead to diverse diseases, such as cardiovascular, neural, blood, and bone diseases, as well as gingivitis and kidney failure $[10,11]$. As compared to the adults, the children are more vulnerable to the risks of heavy metals in the dust, because of their habits of crawling, randomly inserting materials into the mouth, sucking fingers, and high respiratory rate that increase the risk of the intake of heavy metals [12,13]. Many studies have been carried out to evaluate and characterize pollution with heavy metals in outdoor dust $[14,15$, 16, 17]. A special attention must be paid to indoor environment dust because the United States Environmental Protection Agency (USEPA) has mentioned that the pollution level in indoor environment is two to five times - and occasionally more than 100 times- greater than in outdoor environment [18]. The sources of indoor environment dust pollution include two types, internal and external pollution sources [19]. The internal sources include cooking, smoking, sweeping, wall erosion, rubber carpet products, painting and other indoor activities [20, 21]. The external pollution sources include traffic emissions, auto repair, welding, waste burning, playground dust... etc., [19]. Many investigations on indoor dust have been conducted in different regions, such as Turkey [20], China [22, 23], and Iran [24]. Characterization of heavy metal pollution level in classroom dust has been carried out in kindergartens and primary school environments in different countries, such as Malaysia [25, 26], Pakistan [27], Nigeria [28], Iran [5], Saudi Arabia [29], and Portugal [30]. As far as we know, there are no published studies on the concentrations of heavy metals in the dust of indoor environments in general, and especially in school environments, in Iraq. Thus, this study is the first to evaluate the levels of heavy metals in the classrooms dust of kindergartens and primary schools in the country. The objectives of this work are to (1) measure some heavy metal concentrations in classrooms dust of the kindergartens and primary schools in Ramadi City, (2) identify the sources of heavy metals in classrooms dust, and (3) assess the pollution level of heavy metals in the classroom dust. 


\section{Materials and Methods Area description}

Ramadi City (Latitude $33^{\circ} 25^{\prime} 51.11^{\prime \prime} \mathrm{N}, 43^{\circ} 17^{\prime} 42.21^{\prime \prime} \mathrm{E}$ ) is the capital of the Anbar Governorate.

Ramadi City has a hot desert climate with low rainfall in the winter. It is characterized by dense traffic and industrial activities. In terms of education on the governorate level, Ramadi is ranked first and have dozens of primary and secondary schools in addition to one public and two private universities. Two kindergartens and 40 primary schools were randomly selected for this work (Figure1). The school locations were recorded by the use of Garmin 72 GPS. There are 13 schools in the vicinity of the roads, 11 schools adjacent to electrical generators, and the other schools are distributed in commercial and residential areas. Based on the age if the school building, there are 17 old and 26 new schools.

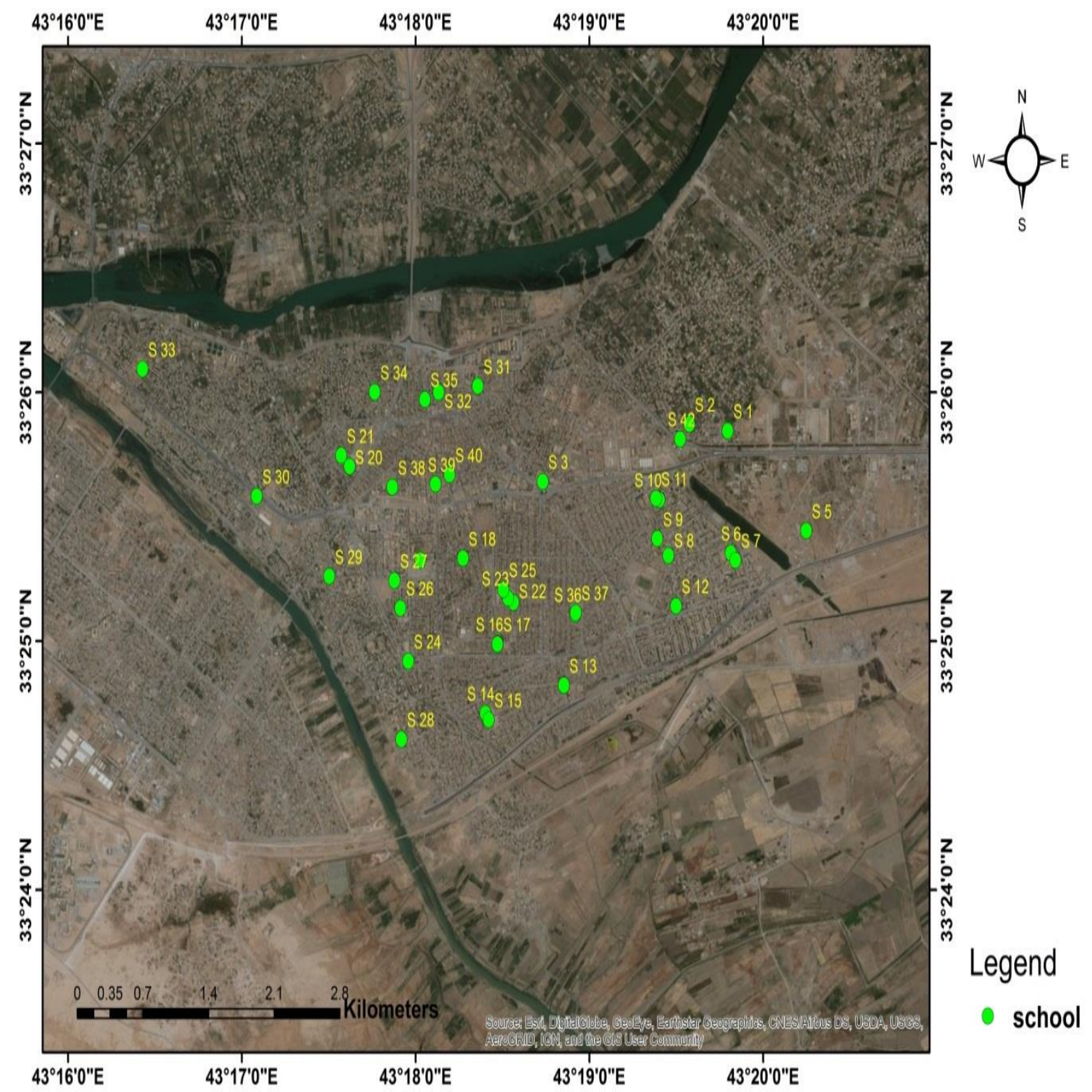

Figure 1-Location map of schools that were selected for dust sampling in Ramadi City, west Iraq. 


\section{Sample collection and analysis}

The dust samples were collected from 40 primary schools and two kindergartens in Ramadi City. The sampling was carried out between October and November 2019. Dust samples from window sills, desks, classroom floor, and playgrounds were collected using plastic brush and pan. About 3-5 samples were collected and mixed to form one composite sample. These dust composite samples were then transferred into individual resalable plastic bags. The samples were dried at $104^{\circ} \mathrm{C}$ for two days and then sieved by using a $106 \mu \mathrm{m}$ stainless steel sieve. The samples were then homogenized with porcelain pestle and mortar. They were kept in a polyethylene container ready for digestion and analysis. Closed vessel microwave-assisted acid digestion technique under high temperature and pressure has become routine [31], which avoids the external contamination and requires shorter time and smaller quantities of acids, thus improving detection limits and overall accuracy of the analytical method [32]. A weight of 0.5 grams of dust sample was put into the reference vessel. Twenty five milliliters of a mixture $\left(\mathrm{HCl}: \mathrm{H}_{2} \mathrm{SO}_{4}: \mathrm{HNO}_{3}, 3: 2: 1\right)$ was then added to the reaction vessel which was inserted into the microwave unit. The digested solution was cooled and filtered. The filtered sample was then made up to $50 \mathrm{ml}$ with distilled water and kept in special containers. AAS (Atomic Absorption Spectrometry) instrument (Phoenix - 986, USA) was used to detect and measure heavy metal content in the dust samples.

\section{Pollution assessment methods}

There are several indices employed to assess the pollution levels in sediment, soil, and dust samples. In our study, the geo-accumulation index $\left(\mathrm{I}_{\mathrm{geo}}\right)$ and pollution load index (PLI) were used to assess the heavy metals pollution level in school dust samples of Ramadi City.

\section{Geo-accumulation index $\left(\mathbf{I}_{\text {geo }}\right)$}

The geo-accumulation index $\left(\mathrm{I}_{\text {geo }}\right)$ was proposed by Muller [33] as a geochemical criterion to assess the heavy metals pollution in sediment and soil. The following formula is used to calculate $\mathrm{I}_{\text {geo: }}$ :

$$
\mathrm{I}_{\text {geo }}=\log _{2}\left(\frac{\mathrm{C}_{\mathrm{n}}}{1.5 \mathrm{~B}_{\mathrm{n}}}\right)
$$

where $C_{n}$ is the measured concentration of metal, $B_{n}$ is the geochemical background values of heavy metals, and the factor 1.5 is introduced to include possible variations of the background values due to geogenic effect. Muller [34] proposed seven different grades for $\mathbf{I}_{\text {geo }}$.

\section{Pollution load index (PLI)}

Pollution level of heavy metals in sediment, soil, and dust is assessed using pollution index (PI), also known as contamination index and pollution load index (PLI), using the following equations [35, 36]:

$$
\begin{gathered}
\mathrm{PLI}=\left(\mathrm{PI}_{1} \times \mathrm{PI}_{2} \times \mathrm{PI}_{3} \times \ldots . . \mathrm{PI}_{\mathrm{n}}\right)^{1 / \mathrm{n}} \\
\mathrm{PI}=\frac{\mathrm{C}_{\mathrm{n}}}{\mathrm{B}_{\mathrm{n}}}
\end{gathered}
$$

where $C_{n}$ is the sample concentration and $B_{n}$ is the background value of the metal. The categories of $\mathrm{Pl}$ are $\mathrm{PI}<1$ (unpolluted), $1 \leq \mathrm{PI}<2$ (slight polluted), $2 \leq \mathrm{PI}<3$ (moderately polluted), and $\mathrm{PI}>3$ (highly polluted).

\section{Quality Assurance and Quality Control (QA/QC)}

These measures include the procedural blank, duplicate analysis, and standard reference materials (BDH from UAE). Recoveries for the elements in the standard reference material were $99.92 \%$ (Cd), 99.22\% (Co), 96.43\% (Cr), 99.43\% (Cu), 98.65\% (Ni), 97.32\% (Pb) and 98.72\% (Zn).

\section{Statistical analysis}

The descriptive statistics, namely the correlation matrix analysis, cluster analysis (CA), and principal component analysis (PCA), were performed using the academic statistics software package STATISTICA - version 13.3 for Windows. The correlation matrix analysis, CA, and PCA were employed to identify the pollution sources and to differentiate geogenic versus anthropogenic contribution. 


\section{Results and Discussion}

\section{Concentration of heavy metals}

The descriptive statistics of the heavy metals concentrations in schools dust in Ramadi City, as well as the background values, are listed in Table- 1 . The results showed that heavy metals concentrations in school dust samples of Ramadi City were, in descending order, as follows: $\mathrm{Cr}>\mathrm{Cu}>\mathrm{Pb}>\mathrm{Ni}>\mathrm{Zn}$ $>\mathrm{Cd}$. The coefficient of variance (CV) values for $\mathrm{Cu}$ (59.43\%), $\mathrm{Cd}$ (44.65\%), $\mathrm{Ni}$ (41.17\%), and $\mathrm{Zn}$ $(40.81 \%)$ were higher than those of $\mathrm{Cr}$, and $\mathrm{Pb}$. This

Table 1-Statistical summary of heavy metals concentrations $(\mathrm{mg} / \mathrm{kg})$ in school dust samples collected in Ramadi City, west Iraq.

\begin{tabular}{|c|c|c|c|c|c|c|c|}
\hline \multirow{2}{*}{ Metal } & \multirow[b]{2}{*}{ Mean } & \multirow[b]{2}{*}{ minimum } & \multirow[b]{2}{*}{ maximum } & \multirow[b]{2}{*}{ Std.dev. } & \multirow[b]{2}{*}{ Coef.Var. } & \multicolumn{2}{|c|}{ Guidelines } \\
\hline & & & & & & $\begin{array}{c}\text { Background } \\
\text { value } \\
{[27]} \\
\end{array}$ & $\begin{array}{c}\text { WHO } \\
\text { [37] }\end{array}$ \\
\hline $\mathrm{Cd}$ & 6.16 & 1.950 & 12.15 & 2.75 & 44.65 & 0.3 & 3 \\
\hline $\mathrm{Cr}$ & 65.68 & 49.150 & 103.95 & 15.49 & 23.58 & 90 & 100 \\
\hline $\mathrm{Cu}$ & 54.28 & 16.700 & 184.60 & 32.26 & 59.43 & 45 & 100 \\
\hline $\mathrm{Ni}$ & 45.82 & 12.800 & 100.05 & 8.861 & 41.17 & 68 & 50 \\
\hline $\mathrm{Pb}$ & 51.46 & 27.150 & 87.85 & 8.76 & 17.03 & 20 & 100 \\
\hline $\mathrm{Zn}$ & 43.90 & 16.650 & 96.20 & 17.91 & 40.81 & 95 & 300 \\
\hline
\end{tabular}

The results suggest that $\mathrm{Cu}, \mathrm{Pb}, \mathrm{Zn}$, and $\mathrm{Cd}$ had greater variation among the dust samples

And, tthus, may be influenced by external factors such as anthropogenic activities [38]. To date, there are no national guidelines for soil or dust in Iraq; therefore, the mean concentration values of heavy metals were compared with the international guidelines. The mean concentrations of $\mathrm{Cd}, \mathrm{Cu}$, and $\mathrm{Pb}$ in school dust of Ramadi City are higher than the background values, while those of $\mathrm{Cr}, \mathrm{Ni}$, and $\mathrm{Zn}$ are lower than the background values. Compared to WHO guidelines, the mean concentrations of $\mathrm{Cr}, \mathrm{Cu}$, $\mathrm{Ni}, \mathrm{Pb}$, and $\mathrm{Zn}$ were within the permissible guidelines, while that of $\mathrm{Cd}$ exceeded the guideline. It is a common approach to compare the mean concentrations of heavy metals in school dust of different environments [27], regardless of the sampling and analytical procedures [39]. A comparison of heavy metal concentrations in Ramadi School dust with data of the school environment in different countries is shown in Table-2.

Table 2-The heavy metal concentrations $(\mathrm{mg} / \mathrm{kg}$ ) of the school environment in different countries

\begin{tabular}{|c|c|c|c|c|c|c|c|c|}
\hline Country & $\mathrm{N}^{*}$ & $\mathrm{Cd}$ & $\mathrm{Cr}$ & $\mathrm{Cu}$ & $\mathrm{Ni}$ & $\mathrm{Pb}$ & $\mathrm{Zn}$ & Reference \\
\hline Iraq (Present study) & 40 & 6.16 & 65.68 & 54.28 & 54.82 & 51.46 & 43.90 & \\
\hline Pakistan & 40 & 5.17 & 194 & 116 & 53.6 & 230 & 1053 & {$[27]$} \\
\hline Armenia & 12 & 1.18 & 39.1 & 149 & 64.5 & 156 & 170 & {$[40]$} \\
\hline South Africa & 32 & 0.64 & 49.6 & 32.7 & 21.2 & 47.1 & 186 & {$[41]$} \\
\hline Nigeria & 55 & 8.55 & 41.8 & 40.9 & 12.7 & 27.6 & 121 & {$[42]$} \\
\hline
\end{tabular}




\begin{tabular}{|c|c|c|c|c|c|c|c|c|}
\hline Malaysia & 90 & 0.23 & 11.9 & 30.2 & 9.04 & 254 & 145 & [43] \\
\hline China & 97 & - & 150 & 70.8 & 34.6 & 181 & 462 & {$[1]$} \\
\hline India & 210 & 3.75 & 3.28 & 10.5 & 4.02 & 19.3 & 78.1 & {$[44]$} \\
\hline
\end{tabular}

\section{*Number of schools}

The comparison showed that $\mathrm{Zn}$ mean concentration in schools dust of Ramadi, Iraq, was lower than that reported in some countries, while the concentrations of the other heavy metals were higher or lower than those in other countries. These results can be interpreted in terms of the different activities of the heavy metals release sources.

\section{Pollution level}

The results of $\mathrm{I}_{\mathrm{geo}}$ calculation are shown in Figure- 2. According to the results, none of the sampling sites were polluted by $\mathrm{Cr}, \mathrm{Cu}, \mathrm{Ni}$, and $\mathrm{Zn}$. The mean values of $\mathrm{I}_{\text {geo }}$ for $\mathrm{Cd}$ and $\mathrm{Pb}$ were 3.63 and 0.75 , respectively, which indicate that the schools dust in Ramadi city are heavily polluted by $\mathrm{Cd}$ and unpolluted to moderately polluted by $\mathrm{Pb}$.

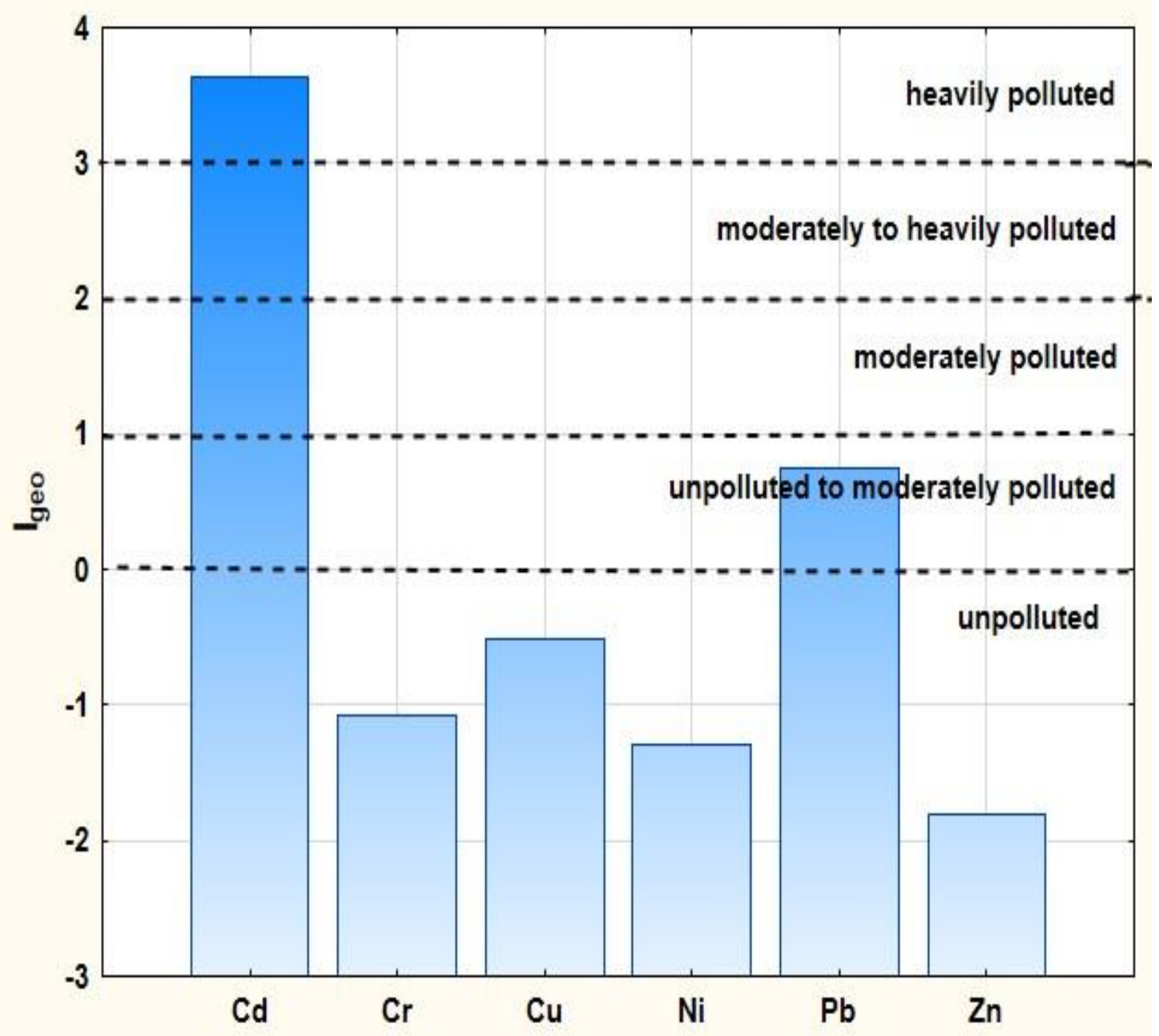

Figure 2-Geo-accumulation index ( $\mathrm{I}_{\mathrm{geo}}$ ) of heavy metals in schools dust samples in Ramadi city.

The heavy pollution of schools dust samples by $\mathrm{Cd}$ and the moderatel pollution by $\mathrm{Pb}$ could be interpreted in terms of being the results of anthropogenic activities. The wide use of plastic toys, paints, painting activities, fertilizers, and insecticides in schools could be a source of Cd [45]. The emissions from fuel burnings are a source of $\mathrm{Pb}$ in school dust collected from the vicinity of dense traffic streets [46]. In our study, the majority of schools are located near streets, and the electrical 
generators are distributed near them. The exhaust emissions from diesel and petrol engines contribute to elevate heavy metals in various environmental media [47]. The PLI values of all heavy metals in schools dust samples of the study area ranged from 1.36 to 3.20, with a mean of 2.01, which indicates no to moderate pollution load.

\section{Correlation matrix analysis}

The results of the correlation matrix analysis were employed to investigate the interrelationships among heavy metals in schools dust in Ramadi City and their potential origins or sources. The strongly significant positive correlation relationships indicate common origin / source and routes of heavy metals. The results of Pearson's correlation coefficient for heavy metals in the schools dust of Ramadi City are listed in Table-3.

Table 3-The results of Pearson's correlation matrix for heavy metal concentrations in the dust of primary schools in Ramadi City

\begin{tabular}{|c|c|c|c|c|c|c|}
\hline Metal & $\mathrm{Cd}$ & $\mathrm{Cr}$ & $\mathrm{Cu}$ & $\mathrm{Ni}$ & $\mathrm{Pb}$ & $\mathrm{Zn}$ \\
\hline $\mathrm{Cd}$ & 1.0 & \multirow[b]{2}{*}{1.0} & \multirow{3}{*}{1.0} & \multirow{5}{*}{1.0} & \multirow{6}{*}{1.0} & \multirow{7}{*}{1.0} \\
\hline $\mathrm{Cr}$ & 0.23 & & & & & \\
\hline $\mathrm{Cu}$ & $0.65^{*}$ & $0.33^{*}$ & & & & \\
\hline $\mathrm{Fe}$ & 0.05 & -0.12 & 0.02 & & & \\
\hline $\mathrm{Ni}$ & $0.48^{*}$ & $0.46^{*}$ & $0.57^{*}$ & & & \\
\hline $\mathrm{Pb}$ & 0.15 & 0.15 & 0.01 & 0.03 & & \\
\hline $\mathrm{Zn}$ & 0.18 & $0.63^{*}$ & 0.29 & $0.47^{*}$ & 0.00 & \\
\hline
\end{tabular}

"Marked correlations are significant at $\mathrm{P}<0.05$.

A significant positive correlation at $\mathrm{P}<0.05$ was found between $\mathrm{Cd}-\mathrm{Cu}(0.65), \mathrm{Cd}-\mathrm{Ni}(0.48), \mathrm{Cu}-$ $\mathrm{Ni}(0.57), \mathrm{Cu}-\mathrm{Cr}(0.33), \mathrm{Ni}-\mathrm{Cr}(0.46), \mathrm{Zn}-\mathrm{Cr}(0.63)$, and $\mathrm{Zn}-\mathrm{Ni}(0.47)$. $\mathrm{Pb}$ is not correlated to the heavy metals taken into account.

Principle component analysis

PCA analyzes a data table representing observations described by several dependent variables, which are generally inter-correlated. The goal of PCA is to extract the important information as a set of uncorrelated (i.e., orthogonal) variables. These variables are called principle components, factors, eigenvectors, singular vectors, or loadings. The proportion of variance explained and the projection of each component express the importance of each component [48]. PCA was used to identify sources of heavy metals in schools dust in Ramadi City by applying varimax rotation with Kaiser Normalization. The results of PCA are listed in Table- 4 and show that there were three eigenvalues with values higher than one, collectively comprising $81.81 \%$ of the total variance. The factor (1) explains $45.92 \%$ of the total variance and has strong positive 
Table 4- Factor loadings (varimax rotation) of heavy metals in schools dust of Ramadi City.

\begin{tabular}{|c|c|c|c|}
\hline Metal & Factor & Factor & Factor \\
\hline $\mathbf{C d}$ & $\mathbf{0 . 8 8 ^ { * }}$ & 0.03 & 0.15 \\
\hline $\mathbf{C r}$ & 0.17 & $\mathbf{0 . 8 6}^{*}$ & 0.16 \\
\hline $\mathbf{C u}$ & $\mathbf{0 . 8 7 ^ { * }}$ & 0.20 & -0.05 \\
\hline $\mathbf{N i}$ & 0.65 & 0.51 & -0.05 \\
\hline $\mathbf{P b}$ & 0.04 & 0.04 & $\mathbf{0 . 9 8 ^ { * }}$ \\
\hline $\mathbf{Z n}$ & 0.12 & $\mathbf{0 . 8 9 ^ { * }}$ & -0.07 \\
\hline Eigenvalue & 2.75 & 1.13 & 1.02 \\
\hline Total variance & 45.92 & 18.86 & 17.03 \\
\hline $\begin{array}{c}\text { Cumulative } \\
\text { \% }\end{array}$ & 45.92 & 64.78 & 81.81 \\
\hline
\end{tabular}

\footnotetext{
*Marked loadings are $>0.70$.
}

loadings on $\mathrm{Cd}$ and $\mathrm{Cu}$. Factor (2) explains $18.86 \%$ of total variance and has strong positive loadings on $\mathrm{Cr}$ and $\mathrm{Zn}$. Factor 3 explains $10.04 \%$ of the total variance and has a strong negative loading on $\mathrm{Zn}$.

\section{Cluster analysis (CA)}

Cluster analysis is an exploratory data analysis tool for solving a classification problem. The objective of this tool is to sort the data into groups or clusters. The cluster shows high internal homogeneity and high external heterogeneity [49]. Hierarchical CA, the most common method, starts with each object in a separate group and joins groups together step by step until there is only one group left [50]. The hierarchical cluster analysis (HCA) was carried out by using Ward's method on the standardized data set. The HCA results for heavy metals in schools dust are shown in Figure- 3 as a dendrogram. Figure- 3 shows two clusters, the first includes $\mathrm{Cd}$ and the second contains $\mathrm{Cu}-\mathrm{Zn}-$ $\mathrm{Ni}-\mathrm{Pb}-\mathrm{Cr}$. The cluster 2 includes three subclusters, (1) $\mathrm{Cu}$; (2) $\mathrm{Zn}-\mathrm{Ni}$; (3) Pb-Cr. The subclusters 2 and 3 joint together at high degree of similarity, possibly suggesting a common origin or source. Both subclusters 2 and 3 show high degree of heterogeneity with subcluster 1, may be implying a mixed origin or source. The results of CA may be partially or fully consistent with the results of PCA. The correlation matrix analysis, PCA, and CA have been widely used to identify pollution sources of heavy metals in indoor dust [51 -56].

Identification of heavy metals source

The comparison of heavy metal concentrations, background values, correlation matrix analysis, PCA, and CA were employed to identify the sources of heavy metals in school dust of the study area. The results of the used methods partly confirm each other [56]. Based on the method, three sources of heavy metals in schools dust of Ramadi City could be identified and were listed in Table- 5 . 


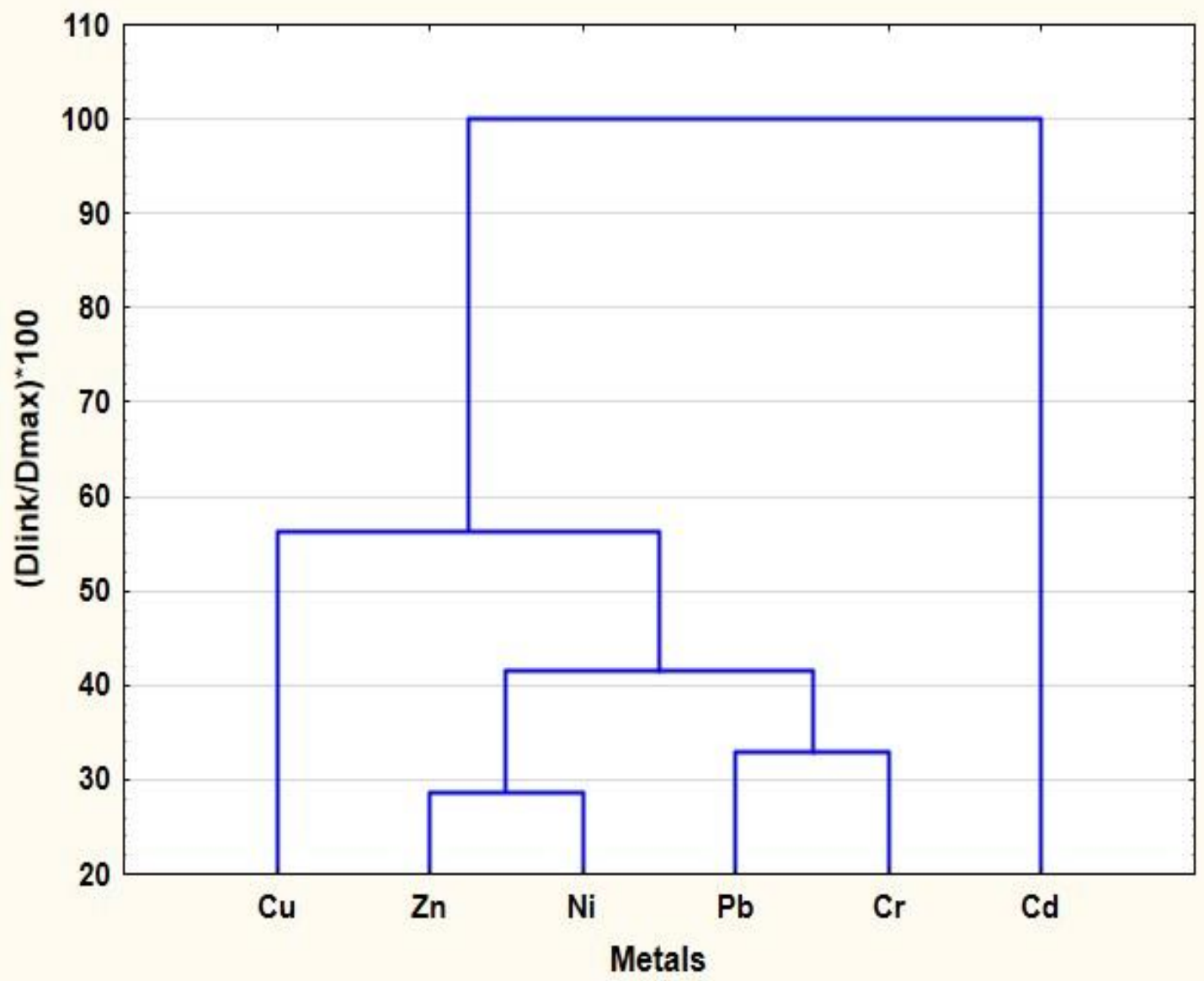

Figure 3-Dendrogram results of hierarchical cluster analysis for heavy metals in schools dust in Ramadi City.

Table 5-The sources of heavy metals in schools dust of Ramadi City

\begin{tabular}{|c|c|c|c|}
\hline \multirow{2}{*}{ Method } & \multicolumn{3}{|c|}{ Sources } \\
\cline { 2 - 4 } & Geogenic & Anthropogenic & Mixed \\
\hline Comparison with background value & $\mathrm{Cr}, \mathrm{Ni}, \mathrm{Zn}$ & $\mathrm{Cd}, \mathrm{Cu}, \mathrm{Pb}$ & \\
\hline Correlation matrix & $\mathrm{Cr}, \mathrm{Zn}$ & $\mathrm{Cd}, \mathrm{Cu}, \mathrm{Ni}$ & $\mathrm{Ni}, \mathrm{Cr}, \mathrm{Cu}$ \\
\hline PCA & $\mathrm{Cr}, \mathrm{Zn}$ & $\mathrm{Cd}, \mathrm{Cu}$ & $\mathrm{Pb}$ \\
\hline CA & $\mathrm{Zn}, \mathrm{Ni}$ & $\mathrm{Cd}, \mathrm{Cu}$ & $\mathrm{Pb}, \mathrm{Cr}$, \\
\hline
\end{tabular}

The results showed three groups; (1) $\mathrm{Cd}$ and $\mathrm{Cu}$ have anthropogenic source; (2) $\mathrm{Pb}$ has mixed source; (3) $\mathrm{Cr}, \mathrm{Ni}$, and $\mathrm{Zn}$ have geogenic source.

The higher Cd concentrations in the dust were linked with vehicle emissions [56], lubricating oil, and tire wear [55]. The emissions from engine diesel fuel and engine wear are one of the $\mathrm{Cd}$ sources [57]. Due to the majority of schools in the study area, that are located near to the streets and electrical power generators, the sources of high $\mathrm{Cd}$ concentration in schools dust are probably vehicle emissions and exhaust emissions from the electrical generators. The emissions from vehicle oils [58], engine wear and tear [59], and traffic emissions [51] were reported as $\mathrm{Cu}$ sources in the outdoor and indoor dust. The lubricant oil combustion in diesel engines and exhaust emissions are also sources of 
$\mathrm{Cu}$ in the ambient environments [51]. The potential sources of $\mathrm{Cu}$ in school dust in the study area are vehicles, diesel engines, and exhaust emissions.

$\mathrm{Pb}$ concentration was higher than the background value, reflecting an anthropogenic origin. $\mathrm{Pb}$ had no significant correlations with the other metals, had very strong loadings in factor 3 of PCA, and was classified with $\mathrm{Cr}$ in the same sub-cluster of $\mathrm{CA}$ image. The classification of $\mathrm{Pb}$ with $\mathrm{Cr}$ in the same sub-cluster can be interpreted based on the fact that geogenic sources contribute to raising $\mathrm{Pb}$ concentration in dust. The emissions from vehicles were reported in previous studies as a main source of $\mathrm{Pb}$ in indoor dust $[9,51]$. The $\mathrm{Pb}$ sources in schools dust in Ramadi City can be interpreted in terms of vehicle emissions and geogenic (local soil) sources.

\section{Conclusions}

The pollution levels of schools dust ranged from unpolluted for $\mathrm{Cu}, \mathrm{Cr}, \mathrm{Ni}$, and $\mathrm{Zn}$, unpolluted to moderately polluted for $\mathrm{Pb}$, and heavily polluted for $\mathrm{Cd}$. The pollution load of all heavy metals in schools dust samples of the study area indicates no to moderate pollution. The origin of $\mathrm{Cd}$ and $\mathrm{Cu}$ is anthropogenic (traffic emissions and exhaust emissions released from the electrical generators spread in the study area). The high $\mathrm{Pb}$ concentrations come from mixed sources (anthropogenic and geogemic sources). The concentrations of $\mathrm{Cr}, \mathrm{Ni}$, and $\mathrm{Zn}$ are of geogenic origin

\section{Acknowledgements}

The authors express their gratitude to Mr. Ahmed Al-Rawi, Lecturer in Department of Chemistry, College of Science / University of Anbar, for his generous help in samples preparation and analysis.

\section{References}

1. Chen, H., Lu, X., Chang, Y., and Xue, w. 2014. Heavy metal contamination in dust from kindergartens and elementary schools in Xi'an, China. Environ. Earth Sci, 71: 2701-2709.

2. Pragg, C. and Mohammed, F. 2019. Distribution and health risk assessment of heavy metals in road dust from an industrial estate in Trinidad, West Indies International Journal of Environmental Health Research, 29:1-8.

3. Tran, D., Alleman, L., Coddeville, P. and Gallo, J. 2012. Elemental characterization and source identification of size resolved atmospheric particles in French classrooms. Atmos. Environ., 54: 250-259.

4. Adekola, F. and Dosumu, O. 2001. Heavy metal determination in household dust from Ilorin City, Nigeria. J. Nigeria Society for Experimental Biology, 3: 217 - 221.

5. Moghtaderi, T., Aminiyan, M., Alamdar, R., and Moghtaderi, M. 2019. Indexed-based evaluation of pollution characteristics and health risk of potentially toxic metals in schools dust of Shiraz megacity, SW Iran. Hum and Ecol Risk Assess Int J 25, https:// doi.org/10. 2080/10807039. 2019.1568857.

6. Gunawardana, C., Egodawatta, P. and Goonetilleke, A. 2014. Role of particle size and composition in metal adsorption by solids deposited on urban road surfaces. Environmental Pollution 184: 44-53.

7. Zheng, J., Chen, K., Yan, X., Chen, S., Hu, G., Peng, X., Yaun, J., Bai, M.and Yang, Z. 2013. Heavy metals in food, house dust, and water from an e-waste recycling area in South China and the potential risk to human health. Ecotoxicology and environmental safety 96:205-212.

8. Bradham, K., Laird, B., Rasmussen, P., Schoof, R., Serda, S., Siciliano, S. and Hughes, M. 2014. Assessing the bioavailability and risk from metal-contaminated soils and dusts. Hum Ecol Risk Assess Int J 20:272-86.

9. Praveena, S., Abdul Mutalib, N. and Aris, A. 2015. Determination of heavy metals in indoor dust from primary school (Sri Serdang, Malaysia): estimation of the health risks. Environ Forensics 16:257-63.

10. Christoforidis, A. and Stamatis, N. 2009. Heavy metal contamination in street dust and roadside soil along the major national road in Kavala's region, Greece. Geoderma 151: 257-263.

11. Shi, G., Chen, Z. and Bi, C., Wang, L., Teng, J., Li, Y. and Xu, S. 2011. A comparative study of health risk of potentially toxic metals in urban and suburban road dust in the most populated city of China. Atmospheric Environment 45:764-71.

12. Tong, T. and Lam, K. 2000. Home sweet home? A case study of household dust contamination on Hong Kong. Sci Total Environ 256: 115-123. 
13. Meza-Figueroa, D., De la O-Villanueva, M. and De la Parra, M. 2007. Heavy metal distribution in dust from elementary schools in Hermosillo, Sonora, México. Atmospheric Environment 41: 276288.

14. Wan, D., Han, Z., Yang, J., Yang, J. and Liu, X. 2016. Heavy Metal Pollution in Settled Dust Associated with Different Urban Functional Areas in a Heavily Air-Polluted City in North China. Int J Environ Res Public Health 13, 1119; doi:10.3390 /ijerph13111119.

15. Xiaoyan, L. 2015. Levels and spatial distribution of heavy metals in urban dust in China. Chin. J. Geochem. 34: 498-506. https://doi.org/ 10.1007/s11631-015-0067-1.

16. Han, X. and Lu, X. 2017. Spatial distribution, environmental risk and source

17. of heavy metals in street dust from an industrial city in semi-arid area of China. Archives of Environmental Protection 43: 10-19. https://doi.org/ 10.1515/aep-2017-0013.

18. Hou, S., Zheng, N., Tang, L., Ji, X., Li, Y., and Hua, X. 2019. Pollution characteristics, sources, and health risk assessment of human exposure to $\mathrm{Cu}, \mathrm{Zn}$, and $\mathrm{Cd}$ and $\mathrm{Pb}$ pollution in urban street dust across China between 2009 and 2018. Environment International 128:430-437. https://doi.org/10.1016/j.envint.2019.04.046.

19. United States of Environmental Protection Agency (USEPA). 2020. Why indoor air quality is important to schools. Resource document. https:// www.epa.gov/iaq-schools/why-indoor-airquality-important-schools. Accessed 28 May 2020.

20. Tan, S., Praveena, S., Abidin, E. and Cheema, M. 2016. A review of heavy metals in indoor dust and its human health -risk implications. Rev Environ Health 31: 447-456. https:// doi.org/ 10.1515/reveh-2016-0026.

21. Wong, C., Li, X. and Thornton, I. 2006. Urban environmental geochemistry of trace metals. Environ. Pollut. 142: 1-16.https:// doi.org/ 10.1016/j. envpol.2005 .09.004.

22. Kurt-Karakus, P. 2012. Determination of heavy metals in indoor dust from Istanbul, Turkey: Estimation of the health risk. Environmental International 50: 47-55.https:// dx.doi.org/10.1016/j.envint.2012.09.011.

23. Li, Y., Fang, F., Lin, Y., Wang, Y., Kuang, Y. and Wu, M. 2019. Heavy metal contamination and health risks of indoor dust around Xinqiao Mining Area, Tongling, China. Hum Ecol Risk Assess Int J . https:// doi.org/10.1080/10807039.2018.1503930.

24. Zhou, L., Liu, G., Shen, M., Hu, R., Sun, M. and Liu, Y. 2019. Characteristics and health risk assessment of heavy metals in indoor dust from different functional areas in Hefei, China. Environmental Pollution 251: 839-849. https:// doi.org/10.10.16/j.envpol.2019.05.058.

25. Ardashiri, S. and Hashemi, S. 2017. Health risk of heavy metals in indoor dust from Bushehr, Iran. Iranian Journal of Health Safety \& Environment 5: 966-971.

26. Latif, M., Young, S., Saad, A., Mohamad, N., Baharudin, N., Mokhtar, M. and Tahir, N. 2013. Composition of heavy metals in indoor dust and their possible exposure: a case study of preschool children in Malaysia. Air Qual Atmos Health. https:// doi.org/ 10.1007/s11869-013-0224-9.

27. Tan, S., Praveena, S., Abidin, E. and Cheema, M. 2018. Heavy metal quantification of classroom dust in school environment and its impacts on children health from Rawang (Malaysia). Environmental Science and Pollution Research. https:// doi.org/10.1007/s11356-018-3396-x.

28. Rehman, A., Liu, G., Yousaf, B., Zia-Ur-Rehman, M., Ali, M., Rashid, M., Farooq, M. and Javed, Z. 2020. Characterizing pollution indices and children health risk assessment of potentially toxic metal (oid) s in school dust of Lahore, Pakistan. Ecotoxicology and Environmental Safety 190: 110059. https:// doi.org/ 10.1016/j.ecoenv.2019.110059.

29. Victor, O., Chukwuemeka, P. and Oluchi, N. 2018. Heavy metals contents and health risk assessment of classroom corner dusts in selected public primary schools in Rivers State, Nigeria. Journal of Environmental Pollution and Human Health 6: 138-147. https:// doi.org/ 10.12691/jephh-6-4-3.

30. Alghamdi, M., Hassan, S., Alzahrani, N. Alzahrani, N., Alzahrani, F. and Khoder, M. 2019. Risk assessment and implications of schoolchildren exposure to classroom heavy metals particles in Jeddah, Saudi Arabia. Int. J. Environ. Res. Public Health 16:5017. https://doi.org/ 10.3390 /ijerph16245017.

31. Madureira, J., Paciência, I., Rufo, J., Severo, M., Ramos, E., Barros, H. and Fernandes, E. 2016. Source apportionment of $\mathrm{CO}_{2}, \mathrm{PM}_{10}$ and VOCs levels and health risk assessment in naturally 
ventilated primary schools in Porto, Portugal. Building and Environment 96: 198- 205. https:// doi.org/10.1016/jbuildenv2015.11.031.

32. Canadian Counsel of Ministers of Environment (CCME) .1999. Canadian water quality guidelines for protection of aquatic life. Canadian Water Quality Index 1.0.Technical Report, Canadian Environmental Quality Guidelines.

33. Valeria, S., Smith, C. and Donovan, A. 2003. Microwave digestion for sediment, soil and urban particulate matter for trace metal analysis. Talanta, 60: 715-723.

34. Muller, G. 1969. Index of geoaccumulation in sediments of the Rhine River. GeoJournal 2: 108118.

35. Muller, G. 1981 The heavy metal pollution of the sediments of Neckars and Its tributary. $A$ Stocktaking Chemische Zeit, 150: 157-164.

36. Faiz, Y., Tufail, M., Javed, M., Chaudhry, M., and Siddique, N. 2009. Road dust pollution of Cd, $\mathrm{Cu}, \mathrm{Ni}, \mathrm{Pb}$ and $\mathrm{Zn}$ along Islamabad expressway, Pakistan. Microchemical Journal, 92: 186-192.

37. Tomlinson, D.L., Wilson, J.G., Harris, C.R., and Jeffrey, D.W., 1980. Problems in the assessment of heavy-metal levels in estuaries and the formation of a pollution index. Helgol. Meeresunters. 33: 566-575. https://doi.org/10.1007/BF02414780.

38. Khan, Z.I., Ugulu, I., Umar, S., Ahmad, K., Mehmood, N., Ashfaq, A., Bashir, H. and Sohail, M. 2018. Potential toxic metal accumulation in soil, forage and blood plasma of buffaloes sampled from Jhang, Pakistan. Bull. Environ. Contam. Toxicol. 101: 235-242. https://doi.org/10. 1007/s00128-018-2353-1.

39. Shi, J., Wang, H., Xu, J., Wu, J., Liu, X., Zhu, H., and Yu, C. 2007. Spatial distribution of heavy metals in soils: a case study of Changxing, China. Environ. Geol., 52: 1-10. DOI: 10.1007/s00254-006-0443-6.

40. Lu, X., Wang, L., Li, L., Lei, K., Huang, L., and Kang, D. 2010. Multivariate statistical analysis of heavy metals in street dust of Baoji, NW China. Journal of Hazardous Materials, 173: 744-749. https:// doi: 10.1016/j.hazmat.2009.09.001.

41. Maghakyan, N., Sahakyan, L., Belyaeva, O., Kafyan, M., and Tepanosyan, G. 2017. Assessment of heavy metal pollution level and children's health risk in a kindergarten area. Natl. Acad. Sci. RA Electron. J. Nat. Sci. 1: 10-15. https://doi.org/10.1016/j.ecoenv.2017.04.013.

42. Olowoyo, J.O., Mugivhisa, L.L., and Magoloi, Z.G. 2016. Composition of trace metals in dust samples collected from selected high schools in Pretoria, South Africa. Appl. Environ. Soil Sci. 2016, 1-9. https://doi.org/10.1155/2016/5829657.

43. Olujimi, O., Steiner, O. and Goessler, W. 2015. Pollution indexing and health risk assessments of trace elements in indoor dusts from classrooms, living rooms and offices in Ogun State, Nigeria. $J$. Afr. Earth Sci. 101: 396-404. https://doi.org/10.1016/j.jafrearsci.2014.10.007

44. Omar, N.A., Ismail, Z.S., Nasir, R.A., Sumari, S.M. and Darus, F.M. 2012. Heavy metals composition of indoor dust in nursery schools building. Procedia - Soc. Behav. Sci. 38: 169-175. https://doi.org/10.1016/j.sbspro.2012.03.337.

45. Habil, M., Massey, D.D. and Taneja, A. 2013. Exposure of children studying in schools of India to PM levels and metal contamination: sources and their identification. Air Qual. Atmos. Heal. 6: 575-587. https://doi.org/10.1007/s11869-013-0201-3.

46. Alam, N., Ahmad, S.R., Qadir, A., Ashraf, M.I., Lakhan, C. and Lakhan, V.C. 2015. Use of statistical and GIS techniques to assess and predict concentrations of heavy metals in soils of Lahore City, Pakistan. Environ. Monit. Assess. 187: 636. https://doi.org/10. 1007/s10661-0154855-1.

47. Saeedi, M., Li, L.Y. and Salmanzadeh, M. 2012. Heavy metals and polycyclic aromatic hydrocarbons: pollution and ecological risk assessment in street dust of Tehran. J. Hazard Mater. 227-228, 9-17. https://doi.org/10.1016/j.jhazmat.2012.04.047.

48. Bharathi, K., Dwivedi, D. and Agarwal, A. 2004. Diesel exhaust particulates characterization for heavy metals. Conference: Proceedings of IASTA Meeting and International Conference on Aerosols Clouds and Indian Monsoon At: IIT KanpurVolume: IASTA Bulletin, 16(1\&2): 9296.

49. Abdi, H. 2003. Multivariate analysis. Encyclopedia for research methods for the social sciences. Thousand Oaks: Sage, 699-702. 
50. McGarigal, K., Cushman, S. A. and Stafford, S. 2013. Multivariate statistics for wildlife and ecology research. Springer Science \& Business Media.

51. McKenna Jr, J. E. 2003. An enhanced cluster analysis program with bootstrap significance testing for ecological community analysis. Environmental Modelling \& Software, 18(3): 205-220.

52. Jin, Y., O'Connor, D., Ok, Y., Tsang, D., Liu, A. and Hou, D. 2019. Assessment of sources of heavy metals in soil and dust at children's playgrounds in Beijing using GIS and multivariate statistical analysis. Environment International 124: 320-328. https://doi.org/10.1016/j. envint. 2019.01.024.

53. Cai, K. and Li, C. 2019. Street Dust Heavy Metal Pollution Source Apportionment and Sustainable Management in A Typical City-Shijiazhuang, China. Int J Environ Res Public Health 16(14): 2625. https://doi.org/10.3390/ijerph16142625.

54. Han, X. and Lu, X. 2017. Spatial distribution, environmental risk and source of heavy metals in street dust from an industrial city in semi-arid area of China. Archives of Environmental Protection 43: 10-19. https:// DOI 10.1515/aep-2017-0013.

55. Skorbiłowicz, M., Skorbiłowicz, E. and Łapiński, W. 2020. Assessment of metal contents, pollution and sources of road dust in the city of Bialystok (Poland). Aerosol Air Qual. Res. https:// doi.org/10.4209/aaqr.2019.10.0518.

56. Men, C., Liu, R., Xu, F., Wang, Q., Guo, L. and Shen, Z. 2018. Pollution characteristics, risk assessment, and source apportionment of heavy metals in road dust in Beijing, China. Science of The Total Environment 612: 138-147. https://doi.org/10.1016/j.scitotenv.2017.08.123.

57. Zgłobicki, W., Telecka, M., Skupiński, S., Pasierbińska, A. and Kozieł, M. 2018. Assessment of heavy metal contamination levels of street dust in the city of Lublin, E Poland. Environmental Earth Sciences, 77: 774. https://doi.org/10.1007/s12665-018-7969-2

58. Dwivedi, D. Agarwal, A. and Sharma M. 2006. Particulate emission characterization of a biodiesel vs diesel-fuelled compression ignition transport engine: A comparative study. Atmospheric Environment, 40:5586-5595.

59. Al-Khashman O.A., 2004. Heavy metal distribution in dust, street dust and soils from the work place in Karak Industrial Estate, Jordan. Atmos Environ 38: 6803-6812. 